\title{
Performance of Mole Drain System for Soybean (Glycine max) -Wheat (Triticum aestivum) Cropping System of Madhya Pradesh
}

\author{
S.S. Dhakad ${ }^{1 *}$, G.R. Ambawatia ${ }^{1}$, Gayatri Verma ${ }^{1}$, Santosh Patel ${ }^{1}$, \\ K.V. Ramana Rao ${ }^{2}$ and Sangiv Verma ${ }^{3}$ \\ ${ }^{1}$ RVSKVV Krishi Vigyan Kendra, Shajapur MP (465001), India \\ ${ }^{2}$ Central Institute of Agricultural Engineering (ICAR), Bhopal, (462038), India \\ ${ }^{3}$ JNKVV Krishi Vigyan Kendra, Betul, India \\ *Corresponding author
}

A B S T R A C T

Keywords

Drainage, Mole drainage, Wheat, Soybean

Article Info

Accepted:

20 January 2018

Available Online:

10 February 2018
A field experiments was conducted during rabi seasons of 2015-16 for wheat crop and during kharif season 2016 for soybean crop to assess growth parameters and economics of mole drain system in vertisols of Shajapur district of Madhya Pradesh. Mole drain system was found better in terms of growth parameters; yield attributes and economics parameters comparison with the control.The net return is the best index of profitability of wheat and soybean crop and higher net return per ha Rs 43256 and Rs 37516 was recorded for wheat and soybean crop respectively under mole drain system where as lower net return per ha of Rs 38006 and Rs 23016 was recorded for wheat and soybean crop respectively under control.

\section{Introduction}

Drainage is an effective tool in combating the negative effects of salinity and water logging (Vardhan et al., 2014). Vertisols (clay soils) occupy over $320 \mathrm{mha}(2.5 \%)$ of the global land area and found under a wide range of climates with major part (about 83\%) under semiarid and arid conditions. Vertisols offer good prospects of production when adequately drained since they suffer from flooding, surface ponding and or waterlogging. Moling is a temporary method of drainage where soil conditions are suitable mole function efficiently for the few first years and then gradually deteriorate. Mole drainage alone, on the hand, usually offers a good solution to drainage problems in most clayed soils. Soil loosening by deep ploughing or subsoiling to improve hydraulic conductivity is only justified in situation where mole drainage would be unsuccessful. The major soil properties influencing the suitability of soils for pipeless drainage are clay content, clay mineralogy, nature of exchangeable cations, type of deposit and bulk density (Spoor et al., 1982). 
Jha (1992) and Jha and Koga (1995) carried out a field experiment in conjunction with soybean crop in the central plain of Bangkok to examine the impact of pipeless drainage on soil properties and plant growth. Pipeless drainage were installed at a depth of $55 \mathrm{~cm}$, spaced $2 \mathrm{~m}$ apart and at $1 \%$ slope by using a mole plough having a torpedo of $8.5 \mathrm{~cm}$ and an expander of $9.5 \mathrm{~cm}$ in diameter. The effects of pipeless drainage on soil physical and chemical properties were found to be very significant: basic infiltration rate increased by about 2.7 fold, porosity increased by $14 \%$ at $25 \mathrm{~cm}$ depth and by $19 \%$ at $40 \mathrm{~cm}$ depth, soil aeration improved markedly, saturated hydraulic conductivity increased by 34 fold at $25 \mathrm{~cm}$ depth and by 61 fold at $40 \mathrm{~cm}$ depth, and pipeless drains with liming showed longlasting improvement in soil $\mathrm{pH}$ and $\mathrm{E}_{\mathrm{C}}$ in the lower soil profile. Because of these improvements in the soil properties it was found that the soybean crop responded very well to pipe less drainage. There was about $46 \%$ increase in grain yield and $118 \%$ increase in the dry matter per plant.

K.V.Ramana Rao et al., (2009) a 4- year (2004-2009) field experiment was carried out at Central Institute of Agricultural Engineering (CIAE), Bhopal feasibility of mole drainage for draining excess rain water in vertisols. A 56 PS wheel tractor was used in the drawing of mole drains at 2, 4 and $6 \mathrm{~m}$ spacings and at a constant depth of $0.60 \mathrm{~m}$ at grade of $0.8 \%$. The soil moisture content was $22.5 \%$ at moling depth. The quantity of drained water from the plots under each of drain spacing was monitored using water meter. The drained area between each was $480 \mathrm{~m}^{2}, 960 \mathrm{~m}^{2}$ and $1080 \mathrm{~m}^{2}$ for 2,4 and $6 \mathrm{~m}$ drain spacings respectively. The crop yields increased by about $50 \%$ in the mole drained plots as compared to the control. The field capacity of mole plough during formation of mole drains at 2,4 and $6 \mathrm{~m}$ drain spacing were $0.14,0.28$ and $0.42 \mathrm{ha} / \mathrm{h}$ respectively while the cost per ha for construction of mole drains at 2,4 and $6 \mathrm{~m}$ drain spacing were Rs 3200,Rs 1800 and Rs 1200 respectively. Dhakad et al., (2015) concluded that observation on physiological parameters like days to germination, days to $50 \%$ flowering and days to $75 \%$ maturity showed non-significant differences due to different treatments (spacing of mole drain, depth of mole drain and interaction of these two) and maximum values of all the parameters were observed under mole drain spacing $\mathrm{S}_{1}(2 \mathrm{~m})$ and mole drain depth $\mathrm{D}_{1}(0.4 \mathrm{~m})$ in most of the cases. Dhakad et al., (2016) concluded that net return is the best index of profitability of crop production and higher net return Rs 64725 per ha and Rs 28325 per ha were recorded for lentil and soybean crop respectively under mole drain areas whereas, the lower net return Rs 31300 per ha and Rs 11900 per ha was recorded under control (No mole drain system) for these crops. From the study, it can be concluded that the mole drains are best option for the water logged vertisols and it is the most appropriate, profitable and productive practice in these soils not only for kharif crops but also for rabi crops. Considering the above aspects an attempt has been made under the present study to effect of mole drainage on soybean -wheat cropping system on vertisols of Madhya Pradesh.

\section{Materials and Methods}

The study area is located in the farmer's fields in the village Duglay, Tilabadgoving and Chhapri in Shajapur district of Madhya Pradesh. The dimensions of the mole plough designed and developed at CIAE include a leg with $1250 \times 250 \times 25 \mathrm{~mm}$ and a foot of 63 $\mathrm{mm}$ with $75 \mathrm{~mm}$ bullet or expander diameter. With a 3 point linkage the plough can be mounted on a four wheeled drive $75 \mathrm{HP}$ tractor. The mole drains formed at $2 \mathrm{~m}$ spacing with $0.6 \mathrm{~m}$ depth along with $50 \mathrm{~m}$ length and soil moisture content was $22.8 \%$ 
at time of mole drain formation at moling depth.The field experiments were conducted during rabi 2015-16 for wheat crop and during kharif 2016 for soybean to assess the effect of mole drainage system on growth characters and yield of wheat \& soybean crop.

Following growth and yields parameters were recorded for lentil and soybean crop

\section{Plant population}

Plant population per running meter was recorded converted in to plants/ ha

\section{Plant height}

Plant height at harvest stage was recorded. In each plot five plants were selected randomly and tagged for periodic observation. The height $(\mathrm{cm})$ was measured from the ground surface to the main stem apex.

\section{Root studies}

Root is a major part of the plant which provides anchoring and active participation in nutrient, moisture uptake and play effective role in fixation of atmospheric nitrogen. For root studies, observation on root length and root nodules was recorded.

\section{Root length}

Five plants were selected randomly from each plot and the length of root was taken in $\mathrm{cm}$. The observation on root length was taken at 60 days after sowing for soybean crop only.

\section{Root nodules per plant}

As the root nodules play a vital role in the productivity, five random plants dug up randomly in each plot and the root was washed for counting the number of nodules for soybean crop only.

\section{No. of seeds per pod}

Total number of seeds removed in 10 randomly selected pods and total seed numbers were counted and averaged.

\section{Seed Index (weight of 100 seeds)}

The seed samples from the produce of each plot were taken and samples comprising of 100 seeds were drawn irrespective by shape and size from the produce and weight of these seeds was recorded.

\section{Seed yield}

The crop were harvested plot-wise and then threshed after the sun drying. The seed yield of each plot was recorded and converted into $\mathrm{kg} / \mathrm{ha}$

\section{Net monetary returns}

Net monetary returns were obtained by subtracting cost of cultivation from gross monetary returns. Net monetary returns are considered to be a good indicator of suitability of a particular cropping system as this represents the accrued net income to the farmer. Net monetary returns (Rs/ha) $=$ Gross monetary return (Rs/ha) - Cost of cultivation (Rs/ha)

\section{Benefit: cost ratio (B: $\mathrm{C}$ ratio)}

It is the ratio of gross return to cost of cultivation and is expressed as returns per rupee invested. Benefit cost ratio $=$ Gross monetary return (Rs/ha)/Cost of cultivation (Rs/ha) The data collected on various characters of selected crop was processed and subjected to statistical analysis by test as suggested William Sealy Gosset (Fisher Box, Joan 1987). First, all the growth and yield attributes of selected crop was analyzed and then the results were over for both the years 
and analyzed. Statistical analysis was carried out by analyze the difference between two treatments using the ' $t$ ' test of significance and the formula for $t$ test is given below

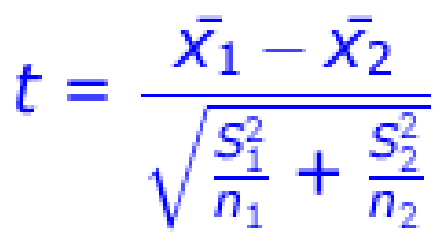

Where,

$\overline{\mathbf{x}}_{1}=$ Mean of first set of values

$\overline{\mathbf{x}}_{2}=$ Mean of second set of values

$\mathrm{S}_{1}=$ Standard deviation of first set of values

$\mathrm{S}_{2}=$ Standard deviation of second set of values

$\mathrm{n}_{1}=$ Total number of values in first set

$\mathrm{n}_{2}=$ Total number of values in second set.

Finally, the calculated ' $\mathrm{t}$ ' value is compared with the theoretical value from a ' $t$ ' table at $5 \%$ probability level. Based on the comparison of calculated ' $t$ ' value with the theoretical ' $t$ ' value from the table, we conclude: If the calculated ' $t$ ' value is greater than the theoretical ' $t$ ' value, then the difference between the two treatments is significant. If the calculated ' $t$ ' value is less than the theoretical ' $t$ ' value, then the difference between the two treatments is not significant.

\section{Results and Discussion}

\section{Performances of mole drainage system for wheat crop}

The higher productivity of $4513 \mathrm{~kg} / \mathrm{ha}$ observed in the treatments with mole drains at $2 \mathrm{~m}$ spacing with $0.6 \mathrm{~m}$ depth, whereas it was found lower under control $(4015 \mathrm{~kg} / \mathrm{ha})$ wheat crop. Higher net return (Rs 43256 per ha) and $\mathrm{B}$ : $\mathrm{C}$ ratio (2.66) was recorded mole drainage system whereas the lower net return (Rs 38006 per ha) and $\mathrm{B}: \mathrm{C}$ ratio (2.51) per ha was recorded under the control plot wheat crop (Table 1). The increase in plant growth parameters and yield might be due to proper aeration and plant growth parameters were better in mole drains plot as compared to control.

\section{Performances of mole drainage system for soybean crop}

Performance parameters were found significantly better in mole drainage system as compared to control for soybean crop. Root is a major part of the soybean crop which provides anchoring and active participation in nutrient, moisture uptake and play effective role in fixation of atmospheric nitrogen.

For root studies, observation on root length and number of root nodules per plant were recorded and analysed statistically through the t test (Table 2).

Root characters of soybean crop was significantly higher in mole drainage system as compared to control in which number of root nodules per plant was $67.7 \%$ more in mole drainage and these root nodules are responsible for the fixation of atmospheric nitrogen in the soil.

The higher productivity of $1683 \mathrm{~kg} \mathrm{ha}^{-1}$ observed mole drainage system whereas lower productivity under control $(1263 \mathrm{~kg}$ $\mathrm{ha}^{-1}$ ) for soybean crop.

The net return is the best index of profitability of soybean crop production and higher net return (Rs 37516 per ha) and B: C ratio (2.75) was recorded under mole drainage system whereas lower net return of (Rs 11900 per ha) and B: C ratio (2.09) was recorded under control. Ramana Rao et al., (2009) and Dhakad et al., (2016) also reported similar findings in their studies on mole drainage technology. 
Table.1 Growth characteristics and yield of wheat for mole drainage system

\begin{tabular}{|r|l|c|c|c|c|}
\hline S.No. & Parameters & $\begin{array}{c}\text { Mole } \\
\text { drainage } \\
\text { system }\end{array}$ & Control & $\begin{array}{c}\text { Increase } \\
\text { in \%o } \\
\text { control }\end{array}$ & $\begin{array}{c}\text { CD } \\
\text { at 5\% }\end{array}$ \\
\hline $\mathbf{1 .}$ & Plant height $(\mathrm{cm})$ at harvest & 84.1 & 79.2 & 6.19 & $\mathrm{~S}$ \\
\hline $\mathbf{2 .}$ & Root length at 60 DAS (cm) & 15.1 & 12.9 & 17.05 & $\mathrm{~S}$ \\
\hline $\mathbf{3 .}$ & Total tillers per m row & 153.2 & 146.8 & 4.36 & $\mathrm{~S}$ \\
\hline $\mathbf{4 .}$ & No. of effective tillers per m row & 140.2 & 134.2 & 4.47 & $\mathrm{~S}$ \\
\hline $\mathbf{5 .}$ & Seed yield $(\mathrm{kg} / \mathrm{ha})$ & 4513 & 4015 & 12.40 & $\mathrm{~S}$ \\
\hline $\mathbf{6 .}$ & Net monetary returns (Rs/ha) & 43256 & 38006 & 13.81 & $\mathrm{~S}$ \\
\hline $\mathbf{7 .}$ & Benefit: cost ratio & 2.66 & 2.51 & 5.98 & $\mathrm{~S}$ \\
\hline
\end{tabular}

Table.2 Growth characteristics and yield of soybean for mole drainage system

\begin{tabular}{|c|l|c|c|c|c|}
\hline S.No. & Parameters & $\begin{array}{c}\text { Mole } \\
\text { drainage }\end{array}$ & Control & $\begin{array}{c}\text { Increase in } \\
\text { \% control }\end{array}$ & $\begin{array}{c}\text { CD } \\
\text { at 5\% }\end{array}$ \\
\hline $\mathbf{1 .}$ & $\begin{array}{l}\text { Plant population (No.m }{ }^{-2} \text { ) at } \\
\text { harvest }\end{array}$ & 46.22 & 36.11 & 28.00 & S \\
\hline $\mathbf{2 .}$ & Plant height (cm) at harvest & 59.8 & 42.6 & 40.38 & S \\
\hline $\mathbf{3 .}$ & Root Length (cm) at 60 DAS & 22.14 & 14.86 & 48.99 & S \\
\hline $\mathbf{4 .}$ & $\begin{array}{l}\text { Number of root nodules/plant at } \\
\text { 60 DAS }\end{array}$ & 33.11 & 21.34 & 55.15 & S \\
\hline $\mathbf{5 .}$ & Number of seeds per pod & 2.52 & 2.31 & 9.09 & S \\
\hline $\mathbf{6 .}$ & Seed yield weight per plant (g) & 5.36 & 4.63 & 15.77 & S \\
\hline $\mathbf{7 .}$ & Seed Index (g) & 11.11 & 11.08 & 0.27 & NS \\
\hline $\mathbf{8 .}$ & Seed yield (kg/ha) & 1683 & 1263 & 33.25 & S \\
\hline $\mathbf{9 .}$ & Net monetary returns (Rs/ha) & 37516 & 23016 & 63.00 & S \\
\hline $\mathbf{1 0 .}$ & Benefit: cost ratio & 2.75 & 2.09 & 31.58 & S \\
\hline
\end{tabular}

In conclusions, effect of mole drainage system in wheat and soybean crop found better in all comparison over control due to safe removal of excess rain water, timely sowing of crops, proper aeration in root zone of crop in wheat and soybean crop. Net return and $\mathrm{B}: \mathrm{C}$ ratio of mole drain system were found most profitable during kharif as well as rabi.

\section{References}

Dhakad SS, Ramana Rao KV 2015. Visual parameters of soybean (glycine max 1.) as influences by mole drain spacing and depth in vertisols of Madhya Pradesh.Scientific Journal Agricultural Engineering XL (2): 107-115

Dhakad SS, Ramana Rao KV, Umat Rajiv,Ambawatia GR, Khedkar NS and Verma Gayatri 2016. Economic feasibility of mole drainage system in waterlogged vertisols in Malwa region of Madhya Pradesh. Ecology, Environment and Conservation 22 (September Suppl.): 307-311. 
Fisher Box Joan 1987. Guinness, Gosset, Fisher, and Small Samples. Statistical Science 2 (1):45-52

Jha, MK 1992. Studies on mole drainage in Bangkok clay soil. M. Eng. Thesis no. AE-92 -51, AIT, Bangkok. Thailand (unpublished).

Jha, MK and Koga 1995. Mole drainage: prospective drainage solution to Bangkok clay soil. Agriculture water management 28(3):253-270.

Ramana Rao KV, Kishore Ravi and Singh Ramadhar 2009b. Mole drainage to enhance soybean production in waterlogged vertisols. Journal of
Agricultural Engineering 46(4): 54-58. Spoor, G, Leeds-Harrison, PB and Godwin RJ 1982. Some fundamental aspects of the formation, stability and failure of mole drainage channels. Journal of soil science 33(3): 411-425.

Vardhan Vishnu Sidlagatta, Chilamkuthy Sreenivas, Reddy Chinta Venkat and Sreedevi, Pandraju 2014. Impact Assessment of Drainage Water Management in Salt Affected Soils of Godavari Western Delta on a Pilot Scale in India. Scientific Journal Agricultural Engineering XXXIX (3):63-71.

\section{How to cite this article:}

Dhakad, S.S., G.R. Ambawatia, Gayatri Verma, Santosh Patel, K.V. Ramana Rao and Sangiv Verma. 2018. Performance of Mole Drain System for Soybean (Glycine max) -Wheat (Triticum aestivum) Cropping System of Madhya Pradesh. Int.J.Curr.Microbiol.App.Sci. 7(02): 21072112. doi: https://doi.org/10.20546/ijcmas.2018.702.251 